Volume $4 \cdot$ Nomor $3 \cdot$ Juni 2021

Pege (Hal.) : $380-393$

(C) Universitas Pamulang

JL.Surya Kencana No.1 Pamulang, Tangerang Selatan - Banten

Telp. (021) 7412566, Fax (021) 7412491

website. :

Email : jurnalmarketing.unpam@gmail.com

\title{
Pengaruh Citra Merek, Kualitas Produk dan Promosi Online Terhadap Keputusan Pelanggan di Kota Batam Dalam Membeli Skincare Merek Korea
}

\author{
Hengky ${ }^{1}$, Novianto ${ }^{2}$, Amalia Putri Yulandi ${ }^{3}$, Dandhytya Andrea Puspa ${ }^{4}$, Henly ${ }^{5}$ \\ 1-5 Universitas Internasional Batam, email: 1931008.hengky@uib.ac.id, 1931037.novianto@uib.edu, \\ 1931025.amalia@uib.edu, 1931044.dandhytya@uib.edu, 1931082.henly@uib.edu.
}

\begin{abstract}
Abstrak. Produk merek Korea menjadi salah satu produk yang sangat banyak digunakan pada saat ini karena budaya Korea yang sedang naik daun. Skincare merek Korea menjadi salah satu produk yang diburu oleh masyarakat Batam. Penelitian ini dibuat untuk mencari tahu pengaruh antara citra merek, promosi online, dan kualitas produk terhadap keputusan konsumen dalam pembelian skincare merek Korea. Sampel dan objek yang digunakan untuk penelitian ini adalah masyarakat di Kota Batam. Metode yang kami gunakan pada penelitian ini adalah disproportionate random sampling. Jumlah sampel responden yang kami uji sebanyak 432 data dengan menggunakan metode regresi berganda. Aplikasi yang digunakan pada penelitian ini adalah IBM SPSS StatisticS 24. Hasil yang kami dapatkan dalam uji hipotesis adalah terdapat pengaruh signifikan antara citra merek, kualitas produk, dan promosi online terhadap keputusan pembelian skincare merek Korea di Kota Batam. Penelitian ini bermanfaat bagi para manajer pemasaran dalam menentukan strategi dalam melakukan penjualan skincare merek Korea di Kota Batam.
\end{abstract}

Kata Kunci: Citra merek; Keputusan Pembelian; Kota Batam; Kualitas produk; Promosi online; Skincare merek Korea.

\begin{abstract}
Korean brand product has been one of the products that have a huge demand right now because of the popularity of Korean culture. Korean brand skincare has become one of the products that have been hunted by Batam communities. This research intended to find out the influence between brand, online promotion, and product quality on customer decision in buying Korean branded skincare. The sample and the object used in this research is disproportionate random sampling. The total respondent in our sample we used was 432 data using multiple regression methods. The application that we used to test the data is IBM SPSS Statistics 24. The results of hypothesis testing state that there is the significant influence for the brand, online promotion, and product quality on customer decision in buying Korean branded skincare at Batam. This research is useful for marketing manager in determining which strategy to use on selling Korean brand skincare in Batam city.
\end{abstract}

Keywords: Batam City; Brand image; Buying Intention; Korean branded skincare; Product quality; online promotion. 


\section{A. PENDAHULUAN}

Promosi online atau promosi dalam jaringan adalah salah satu jenis cara promosi yang sangat terkenal pada saat ini. Promosi online dapat terkenal karena perkembangan teknologi yang sangat pesat di bidang media sehingga cara promosi tersebut dapat disebarkan ke seluruh dunia. Hal ini lebih bagus dibandingkan promosi secara tradisional yang hanya mencakup daerah hingga satu negara saja.promosi online juga menjadi salah satu bagian dari cara marketing di dalam jaringan. (Lai \& Vinh, 2013) Media untuk melakukan promosi online sangatlah luas, seperti youtube, instagram, facebook dan media lainnya yang sudah mencapai jutaan hingga ratusan juta pengguna dan memiliki jutaan pengguna aktif setiap harinya. Oleh karena itu, banyak sekali produk yang memanfaatkan media tersebut untuk mempromosikan produk mereka. Bahkan, pekerjaan baru pun tercipta dari media tersebut seperti jasa endorse, influencer dan yang lainnya. Promosi online tidak dapat dilakukan jika sebuah produk tidak memiliki Citra merek karena konsumen tidak dapat memastikan apakah produk yang mereka beli sesuai dengan yang dipromosikan di media massa.

Citra merek adalah sebuah nama yang dipersepsikan di sebuah produk yang dibentuk dari informasi dan pengalaman pada masa lalu pelanggan (Lee et al., 2011). Citra merek sangat berpengaruh terhadap sikap konsumen saat melakukan pembelian, mulai dari produk hingga jasa. Citra merek menggambarkan sebuah hubungan atau identitas sebuah produk dengan konsumen. Dengan adanya citra merek yang baik di dalam sebuah produk, konsumen akan lebih cenderung membeli produk tersebut dibandingkan produk yang memiliki citra merek yang tidak baik maupun produk yang sedang meningkatkan citra merek mereka. Contoh pengaruh citra merek terhadap konsumen adalah produk dari perusahaan apple yang berhasil menetapkan identitas citra merek mereka di dunia sehingga banyak sekali konsumen yang membeli produk mereka dengan hanya mengetahui bahwa produk yang mereka beli dibuat dari perusahaan apple, bahkan beberapa konsumen rela menunggu berhari-hari hanya untuk membeli produk buatan apple yang terbaru walaupun ada banyak sekali pilihan lain yang kualitasnya sama dengan harga yang lebih murah. Meskipun citra merek sangat penting bagi sebuah produk, tetapi citra merek tidak dapat menaikkan tingkat penjualan jika kualitas produknya tidak sesuai dengan permintaan pelanggan.

Kualitas produk adalah kondisi sebuah barang yang memiliki tingkat mutu sesuai apa yang di ekspektasi oleh konsumen. Pada saat membeli sebuah produk, kualitas produk adalah salah satu hal yang dipertimbangkan oleh para pembeli (Weenas, 2013). Sesuai hukum ekonomi, semakin banyak sebuah produk maka akan menurunkan tingkat kebutuhan sehingga para pembeli cenderung mencari yang terbaik dengan harga yang bersaing. Oleh karena itu, perusahaan yang mampu menciptakan produk yang berkualitas dengan harga yang murah dapat menjadi pemenang dari persaingan pasar di produk tersebut. Sebuah produk biasanya dikatakan memiliki kualitas yang tinggi jika kinerja, keandalan, daya tahan, estetika, kemampuan melayani, keistimewaan tambahan dan kesesuaian terhadap spesifikasi produk tersebut sesuai dengan apa yang diminta atau dibutuhkan oleh pelanggan. Setiap budaya memiliki pandangan yang berbeda-beda terhadap kualitas sebuah produk, seperti masyarakat Indonesia yang merasakan kualitas produk di negara Amerika itu sangatlah bagus, tetapi bagi masyarakat Amerika, kualitas produk di negara mereka sendiri kurang baik. Oleh karena itu, kualitas produk dapat dipengaruhi oleh budaya lokal yang ada di suatu negara. 
Budaya adalah sebuah tanda eksistensi pada suatu masyarakat yang tidak dapat dipisahkan (Nisrina et al., 2020). Setiap negara memiliki budaya masing-masing. Begitu juga dengan Indonesia. Indonesia sendiri memiliki berbagai macam budaya dengan media yang berbeda pula, seperti rumah adat, upacara adat, lagu, tarian hingga musik yang mencerminkan jati diri Indonesia. Budaya dapat menyebar ke negara lain. Apalagi pada saat ini, teknologi mendorong perkembangan yang pesat di berbagai bidang, termasuk di media massa. Perkembangan media massa tersebut menciptakan terjadinya persebaran budaya seperti budaya yang sedang terkenal pada saat ini, yaitu budaya korea atau sering disebut juga dengan Kpop (Ri'aeni et al., 2019). Persebaran budaya tersebut terjadi karena banyaknya media massa yang menunjukkan budaya luar dan budaya tersebut menarik perhatian masyarakat lokal yang menyebabkan masyarakat lokal mulai mempelajari lebih lanjut tentang budaya asing tersebut.

Masuknya budaya luar tersebut sangat mempengaruhi perilaku masyarakat lokal, seperti fenomena yang terjadi di Indonesia pada saat ini, yaitu pada saat masyarakat Indonesia, khususnya remaja yang mengikuti budaya korea yang cukup terkenal di dunia ini. hal ini menyebabkan terjadinya perubahan tingkah laku masyarakat Indonesia seperti menjadi lebih konsumtif dalam mengikuti trend-trend yang telah dimulai atau diciptakan oleh para artis maupun influencer dari budaya luar tersebut. Hal ini menyebabkan banyak sekali orang yang mengikuti artis korea yang mereka idolakan, mulai dari gaya bicara, gaya berpakaian, penggunaan kosmetik dan skincare merek korea hingga makanan yang dikonsumsi. Perubahan tingkah laku masyarakat Indonesia dapat menjadi peluang yang sangat besar bagi para perusahaan korea untuk mengekspansi penjualan produk negara tersebut ke negara Indonesia yang memiliki penduduk yang sangat padat ini. seperti skincare yang sangat sering dipromosikan oleh artis korea yang bersangkutan. promosi tersebut mendorong para penggemar artis korea tersebut untuk membeli produk yang dipromosikannya supaya mereka dapat mengikuti apa yang dilakukan oleh artis atau idola yang mereka kagumi. Tidak hanya promosi, citra merek dan kualitas produk juga menjadi salah satu alasan penting yang mendorong masyarakat untuk membeli produk yang ditawarkan tersebut. Dengan permintaan pasar dan populasi masyarakat yang sangat besar, perusahaan skincare merek Korea berencana untuk masuk ke pasar Indonesia.

Tujuan kami melakukan penelitian ini adalah untuk mengetahui faktor promosi online, citra merek dan kualitas produk terhadap pembelian skincare merek korea di kota Batam. Alasan kami memilih kota Batam karena kota Batam adalah kota yang sedang berkembang pesat dan perkembangan tersebut bisa menjadi wadah masuknya budaya korea di kota Batam tersebut. Kami berharap para pengusaha dapat memanfaatkan jurnal ini untuk dijadikan sebagai referensi atau bahan pertimbangan dalam membuat keputusan yang tepat dalam melakukan penjualan skincare merek Korea di kota Batam ini.

\section{B. KAJIAN LITERATUR}

Penelitian ini didasarkan pada hasil penelitian sebelumnya. Salah satu penelitian yang menjadi dasar penelitian kami adalah studi tentang efek citra merek, kualitas produk dan promosi terhadap keputusan konsumen di kota Bangkok. Penelitian tersebut menjelaskan tentang pengaruh citra merek, kualitas produk dan promosi untuk mengukur keputusan konsumen untuk membeli kosmetik merek Korea di kota Bangkok. Metode yang digunakan adalah metode kuantitatif untuk menguji model yang telah dibuat. Dengan menggunakan data dari 160 penduduk lokal, hasil yang didapatkan adalah diantara tiga faktor tersebut, kualitas produk berpengaruh terhadap keputusan konsumen Thailand untuk membeli kosmetik merek Korea di kota Bangkok. (Sataloff et al., 2018) 
Penelitian lainnya berfokus pada faktor-faktor yang mempengaruhi keputusan pembelian produk skincare pada pelajar di Malaysia. Penelitian tersebut mendeskripsikan apa saja faktor-faktor yang memiliki pengaruh yang besar bagi pelajar di Malaysia, khususnya di Kuala lumpur dalam memutuskan untuk membeli skincare tersebut. Studi empiris yang dilakukan terhadap faktor-faktor yang mendorong keputusan pembelian pelajar dengan 100 pelajar di Kuala lumpur menunjukkan hasil yang sangat menarik. Kehalalan, keamanan produk, citra merek, harga dan kualitas produk menjadi faktor paling penting dalam membuat keputusan untuk membeli produk skincare bagi para pelajar Malaysia. (Rani \& Krishnan, 2018)

Penelitian selanjutnya membahas tentang pengaruh beauty vloggers dalam keputusan pembelian yang melibatkan produk skincare. Penelitian tersebut mendeskripsikan tentang apakah beauty vlogger dapat menjadi salah satu faktor yang menyebabkan para konsumen untuk membeli produk skincare yang telah dipromosikan oleh mereka. Metode yang digunakan adalah metode correlational quantitative dengan menggunakan 100 data pelajar berjenis kelamin perempuan. Hasil yang didapatkan adalah beauty vloggers dapat mempengaruhi keputusan pelanggan dalam membeli produk skincare. (Nurvia \& Sarasati, 2021)

Beberapa penelitian yang menyatakan faktor - faktor lain yang mempengaruhi keputusan pembelian konsumen seperti kehalalan (Khan et al., 2020), promosi offline (Liu \& Ling, 2019) atau promosi dengan tatap muka (Prasetya et al., 2019), pengaruh influencer (Nurhandayani et al., 2019), pengaruh promosi artis (Madiawati et al., 2018), pengaruh brand ambassador dan asal negara (Pandika, Ninin S; Sagir, Junaidi; Sri, 2021), hingga pengaruh bahan - bahan dalam pembuatan skincare seperti penggunaan bahan dari tanaman (Mamun et al., 2020) dan produk yang lebih banyak menggunakan air bersih (Martinus \& Anggraini, 2018).

Terdapat sedikit perbedaan pada studi yang dilakukan di Malaysia dibandingkan dengan studi di tempat lain. Hal tersebut didapatkan pada hasil penelitian (Rani \& Krishnan, 2018) yang menyebutkan bahwa kehalalan menjadi salah satu faktor yang mempengaruhi keputusan para pelajar dalam membeli produk skincare sedangkan pada hasil penelitian (Sataloff et al., 2018) tidak menunjukkan bahwa kehalalan menjadi salah satu faktor yang mempengaruhi keputusan pembelian para konsumen. Ada juga penelitian yang menyatakan bahwa kualitas produk adalah salah satu faktor yang paling penting terhadap keputusan pembelian pelanggan (Wahyuni, 2020). Oleh karena itu, kami berniat dalam penelitian kami untuk menguji hasil tersebut dengan data yang kami peroleh di Batam, Indonesia. selain itu dalam penelitian, model penelitian yang kami gunakan adalah TAM dengan instrument yang dipengaruhi oleh (Sataloff et al., 2018). Populasi penelitian kami adalah masyarakat di kota Batam seperti yang dilakukan oleh (Sataloff et al., 2018). Dalam penelitian kami, kami berniat memberikan kontribusi terhada pengetahuan terkait faktorfaktor seperti citra merek, promosi online dan kualitas produk terhadap keputusan pembelian konsumen yang dimana memiliki budaya yang berbeda dengan budaya luar yang lainnya.

\section{METODOLOGI PENELITIAN}

Metode penelitian yang kami gunakan dalam penelitian ini adalah metode kuantitatif. Populasi pada penelitian kami adalah masyarakat Batam yang pernah atau sering menggunakan skincare merek korea dengan menggunakan Disproportionate Random 
Sampling Method. Model penelitian yang kami gunakan adalah model TAM (Technology Acceptance Model) sesuai dengan jurnal referensi kami (Sataloff et al., 2018) dan (Khan et al., 2020).

\section{Teknik Pengumpulan Data}

Metode pengumpulan data dilakukan dengan membagikan kuesioner menggunakan google form yang disebarluaskan melalui media sosial seperti whatsapp, line, instagram maupun secara tatap muka kepada masyarakat dengan tujuan untuk mendapatkan 385 sampel berdasarkan kalkulasi Raosoft terhadap jumlah masyarakat di kota Batam. Data sampel yang kami kumpulkan akan dibagi menjadi beberapa bagian, seperti usia, jenis kelamin, pendapatan bulanan dan frekuensi pembelian skincare merek korea dalam satu tahun terakhir.

\section{Metode Analisis Data}

Metode analisis data yang kami menggunakan aplikasi SPSS dengan menggunakan Pearson Product Correlation untuk uji validitas dan Cronbach's Alpha untuk uji reliabilitas.

\section{Model Penelitian}

Penelitian ini menggunakan model penelitian TAM (Technology Acceptance Model) yang digunakan untuk menyelidiki pengaruh citra merek, kualitas produk dan promosi online terhadap keputusan pelanggan di kota Batam dalam membeli skincare merek Korea. Variabel independen yang digunakan dalam penelitian ini adalah citra merek, kualitas produk dan promosi online dan variabel dependen yang digunakan adalah keputusan pembelian.

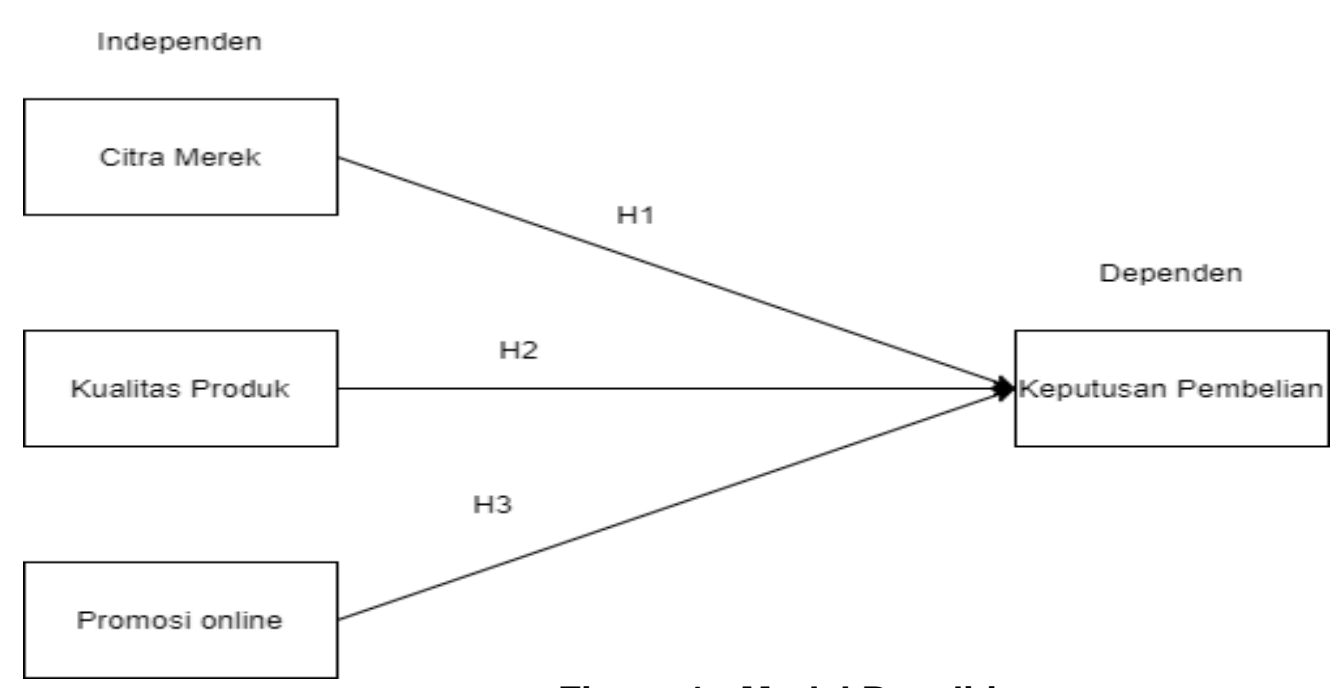

Figure 1 : Model Penelitian

\section{Hipotesis}

Berdasarkan model penelitian ini, terdapat 6 rumusan hipotesis yang akan digunakan dalam penelitian ini, yaitu:

- H1A: Citra merek berpengaruh terhadap pengambilan keputusan pembelian.

- H10: Citra merek tidak berpengaruh terhadap pengambilan keputusan pembelian.

- H2A: Kualitas produk berpengaruh terhadap pengambilan keputusan pembelian.

- H20: Kualitas produk tidak berpengaruh terhadap pengambilan keputusan pembelian.

- H3A: Promosi online berpengaruh terhadap pengambilan keputusan pembelian.

- H30: Promosi online tidak berpengaruh terhadap pengambilan keputusan pembelian. 


\section{Definisi Operasional}

Kuesioner dibuat dan dirancang sesuai dengan instrumen penelitian dengan menggunakan penjelasan dan bukti yang bersangkutan dengan teori dan penemuan dari penelitian sebelumnya. Penelitian dibagi menjadi 4 bagian sebagai berikut:

\begin{tabular}{|c|c|c|c|}
\hline \multicolumn{4}{|c|}{ Tabel 1. Definisi operasional } \\
\hline Variabel & Indikator & Skala & Referensi \\
\hline \multirow[t]{5}{*}{ Citra Merek $\left(\mathrm{X}_{1}\right)$} & $\begin{array}{l}\text { Skincare merek korea memiliki inovasi, } \\
\text { bahan yang lembut, kemasan yang } \\
\text { cantik dan baik untuk kulit }\end{array}$ & \multirow[t]{5}{*}{ Ordinal } & \multirow[t]{5}{*}{$\begin{array}{l}\text { (Sataloff et al. } \\
\text { 2018) }\end{array}$} \\
\hline & $\begin{array}{l}\text { Harga Skincare merek korea sangat } \\
\text { terjangkau dan kualitasnya baik. }\end{array}$ & & \\
\hline & $\begin{array}{l}\text { Skincare merek memiliki reputasi yang } \\
\text { baik di bidang Kesehatan. }\end{array}$ & & \\
\hline & $\begin{array}{l}\text { Skincare merek korea sangat mudah } \\
\text { ditemukan di website belanja online dan } \\
\text { toko lainnya. }\end{array}$ & & \\
\hline & $\begin{array}{l}\text { Skincare merek korea memiliki banyak } \\
\text { pilihan untuk tipe kulit yang berbeda. }\end{array}$ & & \\
\hline \multirow[t]{5}{*}{$\begin{array}{l}\text { Kualitas Produk } \\
\left(\mathrm{X}_{2}\right)\end{array}$} & $\begin{array}{l}\text { Skincare merek Korea memiliki bahan } \\
\text { yang alami dan bersih. }\end{array}$ & \multirow[t]{5}{*}{ Ordinal } & \multirow[t]{5}{*}{$\begin{array}{l}\text { (Sataloff et al., } \\
\text { 2018) }\end{array}$} \\
\hline & $\begin{array}{l}\text { Skincare merek Korea meningkatkan } \\
\text { kondisi kulit pengguna. }\end{array}$ & & \\
\hline & $\begin{array}{l}\text { Skincare merek Korea tidak memiliki } \\
\text { efek samping untuk kulit. }\end{array}$ & & \\
\hline & $\begin{array}{l}\text { Skincare merek Korea diterima oleh } \\
\text { BPOM (Badan Pengawas Obat dan } \\
\text { Makanan). }\end{array}$ & & \\
\hline & $\begin{array}{l}\text { Skincare merek Korea memiliki } \\
\text { kemasan yang menarik dan tidak } \\
\text { mudah rusak. }\end{array}$ & & \\
\hline \multirow[t]{3}{*}{$\begin{array}{l}\text { Promosi Online } \\
\left(\mathrm{X}_{3}\right)\end{array}$} & $\begin{array}{l}\text { Media promosi online Skincare merek } \\
\text { Korea menarik perhatian anda }\end{array}$ & \multirow[t]{3}{*}{ Ordinal } & \multirow[t]{3}{*}{$\begin{array}{l}\text { (Sataloff et al., } \\
\text { 2018) }\end{array}$} \\
\hline & $\begin{array}{l}\text { Media promosi online merek Skincare } \\
\text { Korea informatif }\end{array}$ & & \\
\hline & $\begin{array}{l}\text { Media promosi online merek Skincare } \\
\text { Korea membuat anda ingin membelinya }\end{array}$ & & \\
\hline \multirow[t]{3}{*}{$\begin{array}{l}\text { Keputusan } \\
\text { Pembelian (Y) }\end{array}$} & $\begin{array}{l}\text { Anda memiliki keinginan yang tinggi } \\
\text { untuk membeli Skincare merek Korea }\end{array}$ & \multirow[t]{3}{*}{ Ordinal } & \multirow[t]{3}{*}{$\begin{array}{l}\text { (Sataloff et al., } \\
\text { 2018) }\end{array}$} \\
\hline & $\begin{array}{l}\text { Anda memutuskan untuk membeli } \\
\text { Skincare merek Korea }\end{array}$ & & \\
\hline & $\begin{array}{l}\text { Anda memutuskan untuk membeli } \\
\text { Skincare merek Korea }\end{array}$ & & \\
\hline
\end{tabular}


ISSN NO. (PRINT) 2598-0823, (ONLINE) 2598-2893

\section{Anda memutuskan untuk membeli}

Skincare merek Korea

\section{HASIL DAN PEMBAHASAN}

Data yang didapatkan dari penelitian ini menggunakan cara menyebarkan kuisioner kepada 459 sampel dan kuisioner yang layak diuji adalah sebanyak 432 sampel. Penyebaran kuisioner untuk penelitian ini dilakukan dengan menyebarkan secara online melalui sosial media seperti instagram, line, whatsapp. Untuk mengetahui karakter responden, kami memberikan pertanyaan seperti jenis kelamin, usia, pendapatan per bulan, dan frekuensi penggunaan skincare merek korea dalam satu tahun terakhir. Jumlah sampel yang layak untuk diuji adalah sebanyak 166 responden, sesuai dengan tabel tabel berikut.

Tabel 2. Statistik Kuesioner

\begin{tabular}{cc}
\hline Keterangan & Jumlah \\
\hline Kuesioner yang disebarkan & 459 \\
\hline Kuesioner yang tidak layak & 27 \\
\hline Kuesioner yang layak diuji & 432 \\
\hline
\end{tabular}

Sumber : Data Diolah, 2021

Tabel 3. Jenis Kelamin

\begin{tabular}{ccc}
\hline Jenis Kelamin & Jumlah Responden & Persentase \\
\hline Perempuan & 311 & $72,1 \%$ \\
\hline Laki-Laki & 121 & $27,9 \%$ \\
\hline Total & 432 & $100,0 \%$ \\
\hline
\end{tabular}

Sumber : Data Diolah, 2021

Sesuai dengan data yang didapatkan pada tabel diatas menunjukkan bahwa dari 432 responden, responden dengan jenis kelamin perempuan lebih mendominasi dibandingkan responden laki-laki dengan jumlah perempuan sebanyak 311 (72,1\%) dan responden laki - laki sebanyak $121(27,9 \%)$.

Tabel 4. Usia

\begin{tabular}{ccc}
\hline Usia & Jumlah Responden & Persentase \\
\hline Dibawah 18 Tahun & 42 & $9,8 \%$ \\
\hline $18-25$ Tahun & 309 & $71,5 \%$ \\
\hline $26-35$ Tahun & 43 & $9,8 \%$ \\
\hline $36-45$ Tahun & 27 & $6,3 \%$ \\
\hline 46-55 Tahun & 11 & $2,6 \%$ \\
\hline Diatas 55 Tahun & 0 & $0 \%$ \\
\hline
\end{tabular}

Sumber : Data Diolah, 2021

Sesuai dengan tabel diatas, responden yang paling banyak mengisi kuesioner adalah di jenjang usia antara 18 - 25 tahun dengan persentase sebesar 71,5\% yang hampir mencapai tiga perempat dari seluruh responden. Hal ini menyatakan bahwa sebagian besar pembeli skincare merek Korea berasal dari kalangan remaja jengan usia 18 -25 tahun. 
Tabel 5. Frekuensi Pembelian

\begin{tabular}{ccc}
\hline Frekuensi & Jumlah Responden & Persentase \\
\hline Sebulan sekali & 89 & $20,7 \%$ \\
\hline Dua bulan sekali & 129 & $29,8 \%$ \\
\hline Empat bulan sekali & 90 & $20,7 \%$ \\
\hline Enam bulan sekali & 41 & $9,6 \%$ \\
\hline Setahun sekali & 83 & $19,2 \%$
\end{tabular}

Sesuai dengan tabel diatas, dapat dilihat bahwa sebagian besar responden melakukan pembelian skincare merek Korea setiap dua bulan sekali dengan jumlah responden sebanyak $129(29,8 \%)$. Tidak hanya itu, rata - rata pembelian skincare merek Korea memiliki persentase yang cukup dekat, seperti frekuensi pembelian sebulan sekali dengan jumlah responden sebanyak $89(20,7 \%)$ orang dan setahun sekali sebanyak 90 $(20,7 \%)$ orang.

Tabel 6. Pendapatan Bulanan

\begin{tabular}{ccc}
\hline Pendapatan & Jumlah Responden & Persentase \\
\hline$<2.000 .000$ & 202 & $46,8 \%$ \\
\hline $2.000 .000-4.000 .000$ & 135 & $31,2 \%$ \\
\hline $4.000 .000-7.000 .000$ & 74 & $17,2 \%$ \\
\hline $7.000 .000-10.000 .000$ & 13 & $3,1 \%$ \\
\hline$>10.000 .000$ & 8 & $1,7 \%$ \\
\hline
\end{tabular}

Sumber : Data Diolah, 2021

Sesuai dengan data dari tabel diatas, dapat dilihat bahwa sebagian besar responden memiliki gaji dibawah 2.000 .000 rupiah sebanyak 202 (46,8 \%) orang yang hampir mencapai setengah dari jawaban responden. Hal ini membuktikan bahwa sebagian besar responden merupakan pelajar ataupun penggangguran hingga karyawan yang memiliki gaji dibawah upah minimum.

\section{Hasil Uji Validitas}

Uji validitas dikatakan valid jika $r$ hitung lebih besar dari $r$ tabel sebanyak 0,098 dan masing-masing signifikansi pada variabel yang ada kurang dari 0,05 . Setelah melakukan uji validitas terhadap setiap pertanyaan pada variabel yang ada, dapat dibuktikan bahwa semua variabel dinyatakan valid seperti hasil pengujian yang telah dilakukan sebagai berikut:

1. Untuk Citra merek $\left(\mathrm{X}_{1}\right)$, r hitung yang didapatkan pada CM001 adalah 0,77, CM002 adalah 0,63, CM003 adalah 0,69, CM004 adalah 0,65, CM005 adalah 0,72. Selain itu, signifikansi yang didapatkan dari seluruh variabel diatas menunjukkan angka 0,00 yang menyatakan bahwa Citra Merek dinyatakan valid

2. Untuk Kualitas Produk $\left(\mathrm{X}_{2}\right), r$ hitung yang didapatkan pada KP001 adalah 0,80, KP002 adalah 0,66, KP003 adalah 0,75, KP004 adalah 0,79, CM005 adalah 0,66. Selain itu, signifikansi yang didapatkan dari seluruh variabel diatas menunjukkan angka 0,00 yang menyatakan bahwa Kualitas Produk dinyatakan valid

3. Untuk Promosi Online $\left(X_{3}\right), r$ hitung yang didapatkan pada P001 adalah 0,81, P002 adalah 0,82, P003 adalah 0,83. Selain itu, signifikansi yang didapatkan dari seluruh variabel diatas menunjukkan angka 0,00 yang menyatakan bahwa Promosi Online dinyatakan valid 
4. Untuk Keputusan Pembelian (Y), $\mathrm{r}$ hitung yang didapatkan pada PK001 adalah 0,80, PK002 adalah 0,83, PK003 adalah 0,77, PK004 adalah 0,76. Selain itu, signifikansi yang didapatkan dari seluruh variabel diatas menunjukkan angka 0,00 yang menyatakan bahwa Keputusan Pembelian dinyatakan valid

\section{Hasil Uji Reliabilitas}

Berdasarkan hasil pengujian yang menggunakan Cronbach's Alpha membuktikan bahwa nilai variabel citra merek adalah 0,72 , kualitas produk adalah 0,76 , promosi adalah 0,78 dan keputusan pembelian adalah 0,80 . Berdasarkan nilai variable diketahui nilai cronbach's alpha > 0,70 yang menyatakan bahwa hasil dari pengujian terhadap setiap variabel dapat dikatakan konsisten. Dengan demikian, maka dapat disimpulkan bahwa pengujian realibilitas untuk variable $(X)$ dinyatakan reliabel.

\section{Hasil Uji $\mathbf{R}^{2}$}

Berdasarkan hasil pengujian yang kami dapatkan, nilai koefisien determinasi atau $R$ square adalah 0,49 atau sebesar $49 \%$. Angka ini menyatakan bahwa variabel Citra merek, Kualitas produk, dan Promosi online berpengaruh terhadap Keputusan pembelian sebanyak $49 \%$ dan $51 \%$ lainnya adalah angka variabel luar yang berpengaruh terhadap Keputusan pembelian yang tidak diteliti di penelitian ini.

\section{Hasil Uji F}

Berdasarkan hasil pengujian pada uji $F$, didapatkan nilai sig. sebesar 0,00 dan nilai F hitung sebesar 141,60, maka dapat disimpulkan bahwa hipotesis yang diajukan dapat diterima atau variabel citra merek, kualitas produk, dan promosi online berpengaruh terhadap keputusan pembelian.

\section{Hasil Uji T}

1. Variabel citra merek

Berdasarkan hasil uji t, signifikansi yang didapatkan pada variabel citra merek sebesar 0,00. Hal ini menunjukkan bahwa batas signifikansi 0,05 > signifikansi yang didapatkan sehingga hipotesis yang diajukan dapat diterima dan hipotesis null ditolak.

2. Variabel kualitas produk

Berdasarkan hasil uji t, signifikansi yang didapatkan pada variabel kualitas produk sebesar 0,00. Hal ini menunjukkan bahwa batas signifikansi 0,05 > signifikansi yang didapatkan sehingga hipotesis yang diajukan dapat diterima dan hipotesis null ditolak.

3. Variabel promosi online

Berdasarkan hasil uji t, signifikansi yang didapatkan pada variabel kualitas produk sebesar 0,00. Hal ini menunjukkan bahwa batas signifikansi 0,05 > signifikansi yang didapatkan sehingga hipotesis yang diajukan dapat diterima dan hipotesis null ditolak.

Tabel 7. Hasil Uji t

\begin{tabular}{clcc}
\hline Variabel & B & t & Sig \\
\hline Citra Merek & 0,36 & 5,36 & 0,00 \\
\hline Kualitas Produk & 0,27 & 4,84 & 0,00 \\
\hline Promosi Online & 0,31 & 7,10 & 0,00 \\
\hline & Sumber : Data Diolah, 2021
\end{tabular}

\section{Uji Asumsi Klasik}




\section{Uji Normalitas}

Berdasarkan grafik plot pada gambar 1 dapat dilihat bahwa penyebaran titik-titik plot mengikuti dan mendekati garis diagonal. Hal ini dapat menyimpulkan bahwa data yang didapatkan telah terdistribusi dengan normal.

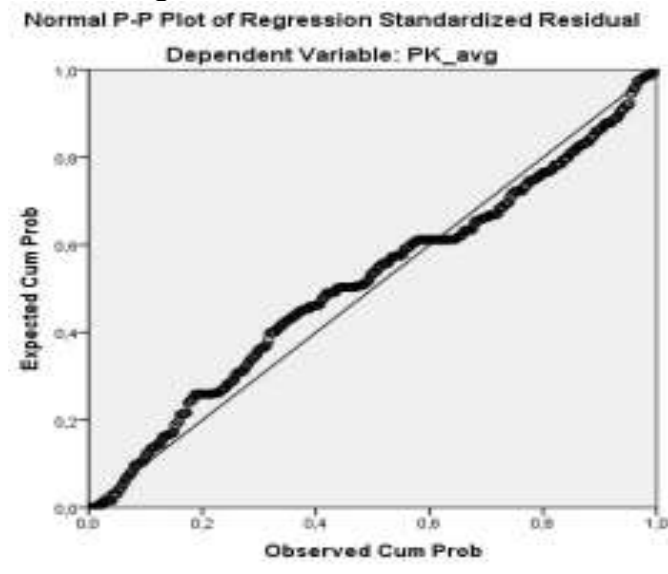

Gambar 1. Hasil Uji Normalitas

Sumber : Data Diolah, 2021

\section{Uji Multikolinearitas}

Berdasarkan uji multikolinearitas menyatakan bahwa nilai Tolerance pada ketiga variabel independen lebih besar dari 0,10 dan nilai VIF dari ketiga variabel independen lebih kecil dari 10,00 sehingga dapat disimpulkan bahwa tidak ada gejala multikolinearitas pada model tersebut.

Tabel 8. Hasil Uji Multikolinearitas

\begin{tabular}{clcl}
\hline Independen & Dependen & Tolerance & VIF \\
\hline Citra Merek & Keputusan Pembelian & 0,43 & 2,32 \\
\hline Kualitas Produk & Keputusan Pembelian & 0,47 & 2,13 \\
\hline Promosi Online & Keputusan Pembelian & 0,65 & 1,55 \\
\hline & Sumber : Data Diolah, 2021
\end{tabular}

\section{Uji Autokorelasi}

Uji autokorelasi yang kami gunakan adalah uji Durbin-Watson. Hasil dari pengujian Durbin-Watson menunjukkan angka 1,827. Dengan melihat tabel Durbin-Watson, dL yang kami dapatkan adalah 1,7382 dan dU yang kami dapatkan adalah 1,7990 dengan $\mathrm{K}=3$ dan $n=200$. Berdasarkan data yang kami dapatkan, nilai Durbin-Watson kami berada diantara batas atas dU dan kurang dari 4-dU. Hal ini dapat membuktikan bahwa tidak ada gejala autokorelasi dari penelitian yang telah kami lakukan.

\section{Uji Heterokedastistias}

Dari gambar 2 Scatterplot dapat dilihat bahwa titik-titik data penyebar bersifat menyebar dan tidak memiliki pola tertentu sehingga dapat dikatakan bahwa model tersebut tidak memiliki kasus heterokedastisitas. 


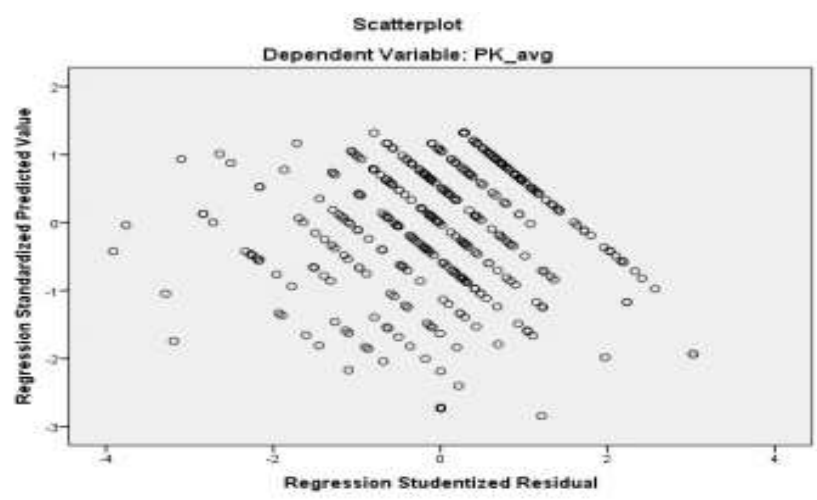

Gambar 2. Hasil Uji Heterokedastisitas

Sumber : Data Diolah, 2021

\section{Analisis Statistik dengan Model Regresi Berganda}

$$
Y=0,19+0,36 X_{1}+0,27 X_{2}+0,31 X_{3}
$$

Berdasarkan persamaan diatas, dapat dikatakan bahwa citra merek, kualitas produk, dan promosi online memiliki pengaruh signifikan terhadap keputusan pembelian pelanggan. Persamaan diatas juga dapat menunjukkan bahwa citra merek adalah variabel yang paling berpengaruh terhadap keputusan pembelian dengan angka sebesar 0,36, disusul oleh promosi online yang memiliki angka sebesar 0,31 dan diikuti oleh kualitas produk yang memiliki angka sebesar 0,27.

\section{E. KESIMPULAN}

Tujuan penelitian ini adalah untuk mengetahui apakah faktor-faktor yang dapat mempengaruhi masyarakat di kota Batam dalam mengambil keputusan pembelian produk skincare merek Korea. Berdasarkan penelitian sebelumnya, citra merek, kualitas produk, dan promosi online dipilih untuk menjadi faktor-faktor yang dipelajari lebih lanjut. Kuesioner didapatkan dari pendapat masyarakat digunakan dan dianalisa menggunakan teknik kuantitatif.

Hasil analisis data menyimpulkan bahwa citra merek dapat mempengaruhi keputusan pembelian pelanggan dalam pembelian skincare merek Korea. Penelitian yang telah diuji ini tidak sesuai dengan penelitian (Sataloff et al., 2018). Citra merek pada konteks ini berarti nama produk yang diciptakan oleh perusahaan yang telah dikenal oleh masyarakat luas. Penelitian ini telah membuktikan bahwa pelanggan akan mempertimbangkan citra merek produk pada saat pelanggan memutuskan untuk membeli sebuah produk skincare merek Korea.

Penelitian ini juga membuktikan bahwa kualitas produk dapat mempengaruhi keputusan pembelian pelanggan dalam pembelian skincare merek Korea. Penelitian ini menyatakan bahwa pelanggan juga akan mempertimbangkan kualitas produk sebagai salah satu faktor yang penting dalam membeli skincare merek Korea. Hasil analisis data ini sesuai dengan penelitian sebelumnya (Sataloff et al., 2018).

Promosi online juga menjadi salah satu faktor yang penting yang mempengaruhi keputusan pembelian pelanggan dalam pembelian skincare merek Korea sesuai dengan hasil dari analisis data yang telah kami uji. Pelanggan akan mempertimbangkan untuk membeli sebuah produk jika melihat orang yang mereka idolakan atau terkenal 
menggunakan produk tersebut, hal itu menciptakan kepercayaan pelanggan yang membuat para pelanggan merasa aman dalam menggunakan produk tersebut. Penelitian ini memiliki hasil yang berbeda dengan penelitian sebelumnya (Sataloff et al., 2018).

Ketiga faktor pada penelitian ini yaitu citra merek, kualitas produk, dan promosi online dapat berpengaruh terhadap keputusan masyarakat di kota Batam dalam mengambil keputusan pembelian produk skincare merek Korea. Bukan hanya skincare merek Korea, penelitian ini juga dapat diaplikasikan kepada skincare yang dibuat dari berbagai negara lainnya.

Budaya Korea telah menyebabkan perubahan tingkah laku sebagian besar masyarakat di kota Batam. Hal ini menyebabkan skincare merek Korea seperti diterima dengan baik oleh masyarakat di kota Batam. Tetapi, banyak sekali faktor yang dapat menyebabkan peningkatan penjualan skincare merek Korea selain asal produksi.

Dari hasil penelitian yang telah kami lakukan membuktikan bahwa masyarakat di kota Batam akan membeli skincare merek Korea dengan citra merek yang telah dikenal oleh masyarakat di kota batam. Penelitian ini juga menjelaskan bahwa kualitas produk juga menjadi salah satu pertimbangan pengguna skincare merek Korea di kota Batam dalam menentukan pembelian skincare merek Korea. Penelitian ini juga menjelaskan bahwa promosi online dapat berpengaruh secara positif terhadap keputusan pembelian skincare merek Korea pada masyarakat di kota Batam. Penelitian ini telah memberikan kontribusi metodologi dengan membuktikan bahwa instrumen penelitian pada penelitian sebelumnya dapat di validasi dan dibuktikan. Penelitian ini dapat membantu para peneliti dalam menambah wawasan tentang faktor - faktor yang dapat mempengaruhi keputusan pembelian skincare di kota Batam.

Penelitian ini juga dapat menjadi referensi bagi para manajer pemasaran dalam menentukan cara dalam melakukan penjualan produk skincare merek Korea pada kota Batam. Sesuai dengan penelitian ini, kami menyarankan untuk memerhatikan ketiga faktor yang kami teliti untuk menjadi pedoman kepuasan pembeli pada masyarakat di kota Batam. Memperlihatkan efek skincare pada kulit pengguna, melakukan promosi online dengan menggunakan jasa artis yang terkenal, memiliki citra merek yang baik di masyarakat, menggunakan pengemasan yang menarik dan menerima umpan balik dari pelanggan dapat menjadi kunci dalam melakukan promosi untuk masyarakat di kota Batam

Penelitian ini dapat dikembangkan lebih lanjut dengan meneliti faktor psikologis dari pelanggan di kota Batam, dengan tujuan untuk mengetahui penyebab desakan dari dalam diri pelanggan dalam membuat keputusan pembelian skincare merek. Korea dan juga melihat apakah pelanggan dari luar kota Batam memiliki pertimbangan yang sama dalam membuat keputusan pembelian skincare merek Korea tersebut. 


\section{DAFTAR PUSTAKA}

Khan, N., Sarwar, A., \& Tan, B. C. (2020). Determinants of purchase intention of halal cosmetic products among Generation Y consumers. Journal of Islamic Marketing. https://doi.org/10.1108/JIMA-11-2019-0248

Lai, W.-H., \& Vinh, N. Q. (2013). Online promotion and its influence on destination awareness and loyalty in the tourism industry. Advances in Management and Applied Economics, 3(3), 15-30.

Lee, H. M., Lee, C. C., \& Wu, C. C. (2011). Brand image strategy affects brand equity after M\&A. European Journal of Marketing, 45(7), 1091-1111. https://doi.org/10.1108/03090561111137624

Lesmana, R., \& Ayu, S. D. (2019). Pengaruh Kualitas Produk Dan Citra Merek Terhadap Keputusan Pembelian Kosmetik Wardah Pt Paragon Tehnology and Innovation. Jurnal Pemasaran Kompetitif, 2(3), 59. https://doi.org/10.32493/jpkpk.v2i3.2830

Lesmana, R., Sunardi, N., Hastono, H., \& Widodo, A. S. (2021). Perceived Quality Membentuk Customer Loyalty via Brand Equity pada Pengguna Smartphone Merek Xiaomi di Tangerang Selatan. Jurnal Pemasaran Kompetitif, 4(2), 157-167

Lesmana, R., Sutarman, A., \& Sunardi, N. Building A Customer Loyalty Through Service Quality Mediated by Customer Satisfaction.

Liu, Z., \& Ling, J. (2019). Research on Influencing Factors of Purchase Promotion Intention Based on Skincare Industry. Modern Economy, 10(03), 1033-1047. https://doi.org/10.4236/me.2019.103069

Madiawati, P. N., Pradana, M., \& Alrasyid, L. (2018). Analysis of Celebrity Endorsement Influence on Purchase Interest: the Case Study of a Skincare Product. The EUrASEANs: Journal on Global Socio-Economic Dynamics, 3(3(10)), 44-51. https://doi.org/10.35678/2539-5645.3(10).2018.44-51

Mamun, A. Al, Nawi, N. C., Hayat, N., \& Zainol, N. R. B. (2020). Predicting the purchase intention and behaviour towards green skincare products among Malaysian consumers. Sustainability $\quad$ (Switzerland), $12(24), \quad$ 1-18. https://doi.org/10.3390/su122410663

Martinus, H., \& Anggraini, L. (2018). The Effect of Sales Promotion in Social Media on the Students: Purchase Intention of Face Cleaner Water Product. Humaniora, 9(1), 15. https://doi.org/10.21512/humaniora.v9i1.4101

Nisrina, D., Widodo, I. A., Larassari, I. B., Rahmaji, F., Kinanthi, G., \& Adi, H. (2020). Studi Tentang Pengaruh Budaya Korea Pada Penggemar K-Pop Diajukan untuk Melengkapi Persyaratan Mencapai Gelar Sarjana Antropologi Sosial. Jurnal Penelitian Humaniora, 21(1), 78-88. 
Nurhandayani, A., Syarief, R., Syarief, R., \& Najib, M. (2019). The Impact of Social Media Influencer and Brand Images to Purchase Intention. Universitas Brawijaya Journal of Applied Management (JAM), 17(4), 650-661. http://dx.

Nurvia, O., \& Sarasati, B. (2021). The Influence of Beauty Vloggers on Purchasing Decisions Involving Skin Care Products. KnE Social Sciences, 2020, 65-79. https://doi.org/10.18502/kss.v4i15.8191

Pandika, Ninin S; Sagir, Junaidi; Sri, D. (2021). Pengaruh brand ambassador dan country of origin terhadap minat beli konsumen pada skin care korea. 7(1), 125-142

Prasetya, N., Santoso, A., \& Wahyuni, S. (2019). Pengaruh Corporate Image dan Word Of Mouth Terhadap Minat Beli Produk Pada Madani Skincare Kediri. JIMEK: Jurnal Ilmiah Mahasiswa Ekonomi, 2(2), 249-264. http://ojs.unikkediri.ac.id/index.php/jimek/article/view/583

Rani, N. S. A., \& Krishnan, K. S. D. (2018). Factors that Influence Malay Students in Purchasing Skincare Products in Malaysia. Journal of Business \& Retail Management Research, 13(01).

Ri'aeni, I., Suci, M., Pertiwi, M., \& Sugiarti, T. (2019). 9460-Article Text-22291-1-1020190422.pdf. In Communications (Vol. 1, Issue 1, p. 2). http://journal.unj.ac.id/unj/index.php/communications/article/view/9460/6798

Sataloff, R. T., Johns, M. M., \& Kost, K. M. (2018). The Effects Of Btand Image, Product Quality and Sales Promotion To Thai consumers Decisions To Purchase Korean Brand Cosmetics In Bangkok District. 67.

Sunardi, N., \& Lesmana, R. (2020). Konsep Icepower (Wiramadu) sebagai Solusi Wirausaha menuju Desa Sejahtra Mandiri (DMS) pada Masa Pandemi Covid19. JIMF (Jurnal IImiah Manajemen Forkamma), 4(1).

Wahyuni, D. S. (2020). Pengaruh Kualitas Produk Terhadap Keputusan Pembelian Skin Care. SELL Journal, 5(1), 55.

Weenas, J. (2013). Kualitas Produk, Harga, Promosi Dan Kualitas Pelayanan Pengaruhnya Terhadap Keputusan Pembelian Spring Bed Comforta. Jurnal Riset Ekonomi, Manajemen, Bisnis Dan Akuntansi, 1(4), 607-618. https://doi.org/10.35794/emba.v1i4.2741 